\title{
Oxalate, magnesium and calcium content in selected kinds of tea: impact on human health
}

\author{
Justyna Brzezicha-Cirocka ${ }^{1} \cdot$ Małgorzata Grembecka $^{1} \cdot$ Piotr Szefer $^{1}$
}

Received: 14 May 2015 / Revised: 7 August 2015 / Accepted: 5 September 2015 / Published online: 7 October 2015

(C) The Author(s) 2015. This article is published with open access at Springerlink.com

\begin{abstract}
The aim of the study was to determine oxalate content in black, dark and green teas as well as to estimate the content ratio of $\mathrm{Mg}$ to $\mathrm{Ca}$ in tea infusions that is significant for patients with kidney stones. Atomic absorption spectrometry was used to determine $\mathrm{Ca}$ and $\mathrm{Mg}$, while oxalate was analyzed by manganometric method. The highest levels of oxalate were found in black and dark tea (156 and $224 \mathrm{mg} / 200 \mathrm{~mL}$, respectively) and the lowest in green tea $(80 \mathrm{mg} / 200 \mathrm{~mL})$. The greatest degree of leaching to tea infusions was determined for $\mathrm{Mg}$ in green (37\%) and black tea $(34 \%)$. The lowest percentage of leaching was estimated for $\mathrm{Ca}(7 \%)$ in black tea. It was concluded that people with hyperoxaluria or a tendency to form kidney stones should consume tea, especially this of darker color, in moderate quantities.
\end{abstract}

Keywords Magnesium $\cdot$ Calcium $\cdot$ Oxalate $\cdot$ Tea $\cdot$ Kidney stones

\section{Introduction}

Tea is one of the most consumed beverages all over the world [1]. There are two species of Camellia sinensis: var. sinensis and var. assamica $[2,3]$. There are different types of tea produced from fresh tea leaves (C. sinensis) [4]. Due to the used processing, the following types of tea can be distinguished: black (fully fermented leaves by oxidizing enzyme), green (non-fermented leaves), oolong

Małgorzata Grembecka

mgrembecka@gumed.edu.pl

1 Department of Food Sciences, Medical University of Gdańsk, Al. Gen. J. Hallera 107, 80-416 Gdańsk, Poland (semi-fermented leaves) and dark tea such as Pu-erh (postfermented leaves by microbes) [5]. Black tea undergoes several hours of full oxidation before steaming and drying, whereas oolong teas undergo partial oxidation; in contrast, green teas are not exposed to any oxidative process [6].

Based on the available scientific literature, it can be stated that drinking tea has a significant impact on human health [15]. It has been shown that tea exhibits anti-oxidative power as well as anti-Alzheimer's effect, and its components also play role in reducing blood pressure and obesity prevention [16]. Besides being health-promoting, tea also contains anti-nutritive compounds such as oxalate. Soluble oxalates are able to bind $\mathrm{Ca}$ and other minerals in acidic to near-neutral conditions, what makes these elements unavailable to the human organism [17].

Liebman et al. [7] reported that tea oxidation leads to the generation of oxalate because the concentration of oxalate is the highest in black teas, intermediate in oolong teas and the lowest in green teas. Moreover, different parts of the same tea plant can contain various levels of oxalate, with younger parts richer in oxalate than the older ones [8]. Black and oolong teas are made from older leaves, and green tea from the flush-containing young leaves [9-11]. Honow et al. [12] concluded that the oxalate content in green tea may vary with time of harvest. Leaves reaped in the autumn, when grown to full size, yielded more oxalate than small and young leaves reaped in the spring. What is more, Morita et al. [13] reported that increasing ammonium in the hydroponic growing media decreased oxalate content in tea plants. The concentration of oxalate can be also changing depending on the time of storage [14].

The bioavailability of oxalate from tea is estimated at 1-9 \% [7]. Oxalate absorption occurs mainly in the intestine through trans- and extracellular way. The highest concentration of oxalate in urine was observed 2-6 $\mathrm{h}$ after food 
Table 1 Characteristics of analyzed products

\begin{tabular}{|c|c|c|c|c|}
\hline Lp. & Name of tea & Producer & Confection & Origin \\
\hline \multicolumn{5}{|c|}{ Green tea } \\
\hline 1. & Saga (green tea) & Unilever Poland S.A. & Bags & Not declared \\
\hline 2. & Vitax Inspirations & Vitax-Multeafil & Loose & Not declared \\
\hline 3. & Green Leafy & Herbapol Lublin S.A. & Loose & Not declared \\
\hline 4. & Tetley Classic & Tata Global Beverages Polska & Bags & India \\
\hline 5. & Green Tea & Carrefour Poland & Bags & Not declared \\
\hline 6. & Green Tea with the quince fruit & Bio-Active Dystribution & Loose & China \\
\hline 7. & Irving ${ }^{\mathrm{TM}}$ Green Superior & Kamis S.A. & Loose & Not declared \\
\hline 8. & Dilmah-Green Tea Sencha & Dilmah-MUF Holdings Ltd. & Bags & Sri Lanka \\
\hline 9. & Teekanne Green Tea & Teekane Poland & Bags & Not declared \\
\hline 10. & Lipton Green Tea Classic & Unilever Poland & Bags & Not declared \\
\hline \multicolumn{5}{|c|}{ Black tea } \\
\hline 11. & Minutka & Mokate S.A. & Bags & Not declared \\
\hline 12. & Sir Roger Earl Grey & Roger S.A. & Bags & Sri Lanka \\
\hline 13. & Saga (black tea) & Unilever Polska S.A. & Bags & Not declared \\
\hline 14. & Twinings $^{\mathrm{TM}}$ Prince of Wales & Twinings $^{\mathrm{TM}} \_\mathrm{AB}$ Food Polska & Bags & China \\
\hline 15. & Tetley & Tata Global Beverages Polska & Bags & India \\
\hline 16. & Yunnan (peach and apricot) & Big Active & Loose & Not declared \\
\hline 17. & Dilmah Premium Tea Ceylon Orange Pekoe & Dilmah-MUF Holdings Ltd. & Loose & Sri Lanka \\
\hline 18. & Loyd Earl Grey & Mokate S.A. & Loose & Not declared \\
\hline 19. & Irving ${ }^{\mathrm{TM}}$ Daily Classic & Irving ${ }^{\mathrm{TM}}$ _Amber Spark S.A. & Bags & Not declared \\
\hline 20. & Lipton Yellow Label Tea & Unilever Polska S.A & Bags & Not declared \\
\hline \multicolumn{5}{|c|}{ Dark tea } \\
\hline 21. & Sir Roger Pu-Erh & Roger S.A. & Bags & China \\
\hline 22. & Irving Tea Spa perfect slim & Kamis S.A. & Bags & Not declared \\
\hline 23. & Vitax Pu-Erh\&Grapefruit & Vitax-Multeafil & Bags & Not declared \\
\hline 24. & Teekane Pu-Erh Tea Lemon & Teekane Poland & Bags & Not declared \\
\hline 25 & Carrefour Tea & Carrefour Poland & Bags & China \\
\hline 26. & Pu-Erh Lemon & Bio-Active Dystribution & Loose & Not declared \\
\hline 27. & Pu-Erh China Leafy & Astra Poznanska Coffee Roaster-Astra & Loose & Not declared \\
\hline 28. & $\mathrm{Pu}$-Erh Grapefruit and orange & 5'o clock Tea and Coffee shops & Loose & China \\
\hline 29. & Pu-Erh Superior & 5'o clock Tea and Coffee shops & Loose & China \\
\hline 30. & Pu-Erh Yunnan & 5'o clock Tea and Coffee shops & Loose & China \\
\hline
\end{tabular}

intake [18]. The effect of oxalate excess in the human body may result in the formation of kidney stones that are insoluble deposits in the urinary tract. This process occurs mainly due to precipitation of chemical substances in the urine when their concentration exceeds solubility limit [19, 20].

Since a continuous increase in the incidence of kidney stones can be observed, it is necessary to consciously control daily diet. It is especially important for patients with a high risk of kidney stones development and other diseases dependent on the oxalate intake such as renal failure or urinary tract infection [21].

The aim of this study was to determine oxalate, magnesium and calcium concentrations in black, dark and green tea and their percentage of leaching to infusions. Furthermore, it was possible to evaluate the content ratio of $\mathrm{Mg}$ to $\mathrm{Ca}$ which is significant for patients with kidney stones. The obtained results allow assessing which species of tea is suitable for consumption by patients with this disease.

\section{Materials and methods}

\section{Sample material}

The analyzed tea samples were purchased from markets in Gdańsk (Poland). There were 270 analytical samples prepared in which oxalate, $\mathrm{Mg}$ and $\mathrm{Ca}$ (in leaves and tea infusions) were determined (Table 1). 
Table 2 The concentration of oxalate, magnesium and calcium in $\mathrm{mg}(\bar{x} \pm \mathrm{SD}$, range) per $200 \mathrm{~mL}$ of tea infusion, the percentage of leaching $(\%)$ and realization of RDA through consumption of $200 \mathrm{~mL}$ of infusion (\%)

\begin{tabular}{|c|c|c|c|c|c|c|c|c|}
\hline Tea & $n$ & $\begin{array}{l}\text { Oxalate } \\
\mathrm{mg} / 200 \mathrm{~mL}\end{array}$ & $\mathrm{Mg} \mathrm{mg} / 200 \mathrm{~mL}$ & $\begin{array}{l}\text { RDA of } \mathrm{Mg}^{\mathrm{a}} \\
(\%)\end{array}$ & $\begin{array}{l}\text { Percentage of } \\
\text { leaching } \mathrm{Mg} \\
(\%)\end{array}$ & $\mathrm{Ca} \mathrm{mg} / 200 \mathrm{~mL}$ & $\begin{array}{l}\text { RDA of } \mathrm{Ca}^{\mathrm{b}} \\
(\%)\end{array}$ & $\begin{array}{l}\text { Percentage of } \\
\text { leaching } \mathrm{Ca}(\%)\end{array}$ \\
\hline Green tea & $9 \times 10$ & $\begin{array}{l}80 \pm 5.2 \\
(49-139)\end{array}$ & $\begin{array}{l}1.68 \pm 0.52 \\
(0.89-2.52)\end{array}$ & $0.40 / 0.52$ & 37 & $\begin{array}{l}0.31 \pm 0.04 \\
(0.02-1.5)\end{array}$ & 0.03 & 14 \\
\hline Black tea & $9 \times 10$ & $\begin{array}{l}156 \pm 18 \\
(51-304)\end{array}$ & $\begin{array}{l}4.39 \pm 1.31 \\
(1.29-5.67)\end{array}$ & $1.04 / 1.37$ & 34 & $\begin{array}{l}3.54 \pm 2.37 \\
(1.39-13)\end{array}$ & 0.35 & 7 \\
\hline Dark tea & $9 \times 10$ & $\begin{array}{l}224 \pm 16 \\
(122-342)\end{array}$ & $\begin{array}{l}1.48 \pm 0.21 \\
(1.14-1.82)\end{array}$ & $0.35 / 0.46$ & 23 & $\begin{array}{l}1.51 \pm 1.17 \\
(0.22-4.70)\end{array}$ & 0.15 & 15 \\
\hline
\end{tabular}

a RDA for Mg for males (31-50 years) is $420 \mathrm{mg} /$ day/person and for females (31-50 years) is $320 \mathrm{mg} /$ day/person [45]

b RDA for Ca for males (31-50 years) and females (31-50 years) is $1000 \mathrm{mg} / \mathrm{day} /$ person [45]

\section{Preparation of samples}

About $10 \mathrm{~g}( \pm 0.0001 \mathrm{~g})$ portions of homogenized products were weighed, and dried material was transferred to quartz crucibles and ashed in an electric furnace $\left(540{ }^{\circ} \mathrm{C}\right)$. Tea brew was prepared from $2 \mathrm{~g}( \pm 0.0001 \mathrm{~g})$ portions of homogenized products and $200 \mathrm{~mL}$ of water and infused for $5 \mathrm{~min}$. Then, the solution was filtered, evaporated to dryness on a boiling water bath and ashed in an electric furnace. The ashed material of tea leaves and tea infusions was mineralized by a mixture of concentrated acids [22].

\section{Analysis of macroelements}

Such prepared solutions were analyzed by AAS using Thermo Scientifics i3000. In case of $\mathrm{Mg}$ and $\mathrm{Ca}, 0.4 \% \mathrm{w} / \mathrm{v}$ lanthanum oxide was added (lanthanum (III) oxide, Merck, Darmstadt, Germany) as a correction buffer.

\section{Analysis of oxalate}

To determine oxalate, $3 \mathrm{~g}$ tea samples were weighed and treated with $100 \mathrm{~mL}$ of water (5 min infused). Ten milliliters of solution was transferred to centrifuge tubes and $5 \mathrm{~mL}$ $5 \% \mathrm{CaCl}_{2}$ and $5 \mathrm{~mL}$ acetone were added. Then, solutions were cooled at $5{ }^{\circ} \mathrm{C}$ for $30 \mathrm{~min}$ and centrifuged for $15 \mathrm{~min}$ (3000 rot $/ \mathrm{min}$ ). The sediment was transferred to the flask with $5 \mathrm{~mL} 10 \% \mathrm{H}_{2} \mathrm{SO}_{4}$ and heated on a water bath $\left(70{ }^{\circ} \mathrm{C}\right)$ until dissolution. Then, it was immediately titrated with a standard solution of $\mathrm{KMnO}_{4}$.

\section{Validation of method}

Reliability of the method was checked using the certified reference materials (Tea, NCS ZC73014 and Tobacco INCT-PVTL-6). Recoveries of the studied elements ranged between 86 and $96 \%$ for tea and 107 and $109 \%$ for tobacco. Precision of the method ranged between 1.6 and $4.4 \%$ for tea and 2.3 and $6.0 \%$ for tobacco.

\section{Results}

\section{Oxalate}

The highest average oxalate level was determined in dark tea $(224 \mathrm{mg} / 200 \mathrm{~mL})$, followed by black tea $(156 \mathrm{mg} / 200 \mathrm{~mL})$ and green tea with its lowest levels $(80 \mathrm{mg} / 200 \mathrm{~mL})$ (Table 2). The highest oxalate level was determined in dark tea Pu-Erh Superior 5'o clock$342 \mathrm{mg} / 200 \mathrm{~mL}$. Among black teas, Sir Roger Earl Grey had the highest levels of oxalate $(304 \mathrm{mg} / 200 \mathrm{~mL})$. The lowest levels of oxalate were determined in green tea with quince fruit-Bio-Active $(49 \mathrm{mg} / 200 \mathrm{~mL})$. Among analyzed tea samples, green tea characterized with the lowest oxalate content, which was in agreement with results reported by Michalak-Majewska [23]. Comparable results were published by Sperkowska and Bazylak [24] for black tea $(178 \mathrm{mg} / 200 \mathrm{~mL})$ and Rusinek [25] for dark tea (204 mg/200 mL). However, according to Rusinek [25], average content of oxalate in black tea infusions was lower and amounted to $116 \mathrm{mg} / 200 \mathrm{~mL}$. According to Sperkowska and Bazylak [26], oxalate content in green tea amounted to $110.2 \mathrm{mg} / 200 \mathrm{~mL}$, which is comparable with results obtained in this study (Table 2). Charier et al. [27] found that non-fermented tea contains lower amounts of oxalate than the fermented one.

\section{Macroelements}

Tea elemental composition varies depending on the geographical origin of tea [28-30], genetic differences [31, 32], the composition of the local soil as well as its characteristics and various agricultural or climatic conditions [3134]. The differences in elemental composition of tea plants 
besides being related to concentrations of these elements in the soils are also dependent on metals' physicochemical forms [35]. What is more, it was implied by couple of authors that the variability in the elemental content of different brands of tea is common and much higher for black teas than for green teas, for which concentration ranges of elements are relatively narrower $[35,36]$. According to Malik et al. [37], the macroelements and microelements levels in particular kinds of tea are not significantly varied, but black teas are usually richer in trace elements than other types of teas, mainly due to the specific way by which these teas are manufactured. In order to produce green tea, leaves are steamed with water vapor, and this process may lead to losses of some elements, whereas leaves for black tea are air-dried so there is not observed loss of elements [38]. Moreover, black and dark teas are usually produced from older leaves, containing higher concentrations of metals, than green tea made from the young leaves [911]. In our study, the levels of $\mathrm{Mg}$ and $\mathrm{Ca}$ were higher in black (4.4 mg Mg/200 mL, $3.5 \mathrm{mg} \mathrm{Ca} / 200 \mathrm{~mL}$ ) than dark (1.5 mg Mg/200 mL, $1.5 \mathrm{mg} \mathrm{Ca} / 200 \mathrm{~mL}$ ) and green teas (1.7 mg Mg/200 mL, $0.3 \mathrm{mg} \mathrm{Ca} / 200 \mathrm{~mL}$ ) (Table 2). Higher levels of $\mathrm{Mg}$ and $\mathrm{Ca}$ in green tea were reported by Malik et al. [37] (3.6 mg Mg/200 mL and $0.79 \mathrm{mg} \mathrm{Ca} / 200 \mathrm{~mL}$ ). However, Malik et al. [37] recorded lower amounts of the analyzed elements in black tea $(3.2 \mathrm{mg} \mathrm{Mg} / 200 \mathrm{~mL}$ and $0.5 \mathrm{mg} \mathrm{Ca} / 200 \mathrm{~mL}$ ). In case of dark tea, Malik et al. [37] reported lower contents of $\mathrm{Ca}(0.42 \mathrm{mg} \mathrm{Ca} / 200 \mathrm{~mL})$, but higher of $\mathrm{Mg}$ (2.0 mg Mg/200 mL). Comparable average levels of $\mathrm{Mg}$ and $\mathrm{Ca}$ in dark tea $(1.24 \mathrm{mg} \mathrm{Mg} / 200 \mathrm{~mL}$ and $1.8 \mathrm{mg} \mathrm{Ca} / 200 \mathrm{~mL}$ ) were published by Malinowska et al. [39].

\section{Percentage of leaching}

The extraction effectiveness of elements into tea infusions depends on whether they are strongly bound to the organic matrix or more soluble in the solution [40]. Most of the elements in tea leaves are complexed by flavonols, catechols, tannins and polyphenols [11]. With respect to this, better leaching of some essential macroelements and trace elements from leaves into infusions was reported for green teas rather than black and oolong teas [1, 33, 37, 41]. The variation in $\mathrm{Ca}$ extraction from the analyzed teas can be explained by the differences in plant's age at harvest or tea-growing conditions. Black and oolong teas are usually produced from older leaves than green tea made from the flush-containing young leaves [9-11].

In our study, magnesium characterized with the highest percentage of leaching, especially in green (37\%) and black tea (34\%) (Table 2). The latter is comparable with values reported by Dambiec et al. [42]. Calcium was poorly extractable (7-15\%), similarly to what was suggested by Szymczycha-Madeja et al. [35]. Gallaher et al. [43] reported lower percentages of extraction of $\mathrm{Mg}(19 \%)$ in green teas, but comparable for $\mathrm{Ca}(7 \%)$ (Table 2). In case of dark tea ( $23 \% \mathrm{Mg}$ and $15 \% \mathrm{Ca}$ ), percentage of leaching was comparable for both of elements and similar to results obtained by Malinowska et al. [39] (29 \% Mg and $17 \%$ $\mathrm{Ca})$.

\section{Statistical analyses}

The results were also analyzed by Spearman's ranks correlation analysis, Kruskal-Wallis test and cluster analysis (CA). First of all, the data were checked for normal distribution. In all of the analyzed cases, there was no normal distribution, and, therefore, nonparametric tests were applied [44].

Correlation analysis for the analyzed elements was performed at three levels of significance $(p<0.05, p<0.01$, $p<0.001)$. There were two positive correlations recorded $(p<0.05)$, i.e., between the kind of tea and $\mathrm{Ca}$, and $\mathrm{Ca}-$ $\mathrm{Mg}$. There was also recorded one positive correlation between the kind of tea and oxalate $(p<0.01)$.

The Kruskal-Wallis test showed statistically significant differences between the type of tea and $\mathrm{Ca}(H=19.12$, $p=0.0001), \operatorname{Mg}(H=13.88, p=0.001)$ and oxalate $(H=11.17, p=0.004)$. The cluster analysis (CA) was performed using Ward method and Euclidean distance. Figure 1a presents the dendrogram, which is built of three main clusters containing commercial samples of particular kinds of tea. It can be observed that CA made it possible to differentiate tea samples in view of tea type with respect to its content of oxalate, $\mathrm{Mg}$ and $\mathrm{Ca}$. As it can be seen in Fig. $1 \mathrm{~b}, \mathrm{Mg}$ is responsible for the differentiation of green tea, which is consistent with its high content in this type of tea, as compared with the remaining components. Other kinds of tea, i.e., black and dark, were described by oxalate and $\mathrm{Ca}$, respectively. Cluster analysis has proven to be a good tool for tea samples differentiation in terms of its components.

\section{Recommended Dietary Intake}

Recommended daily intake (RDA) was calculated for green, dark and black tea infusions according to the latest available Polish recommendations for males and females (31-50 years [45] (Table 2). RDAs for $\mathrm{Ca}$ are realized in the range of $0.03,0.15$ and $0.35 \%$ by consumption of $200 \mathrm{~mL}$ of black, green and dark teas, respectively. Realization of RDA for $\mathrm{Mg}$ by green and dark teas $(0.03,0.03 \%)$ was lower than by black tea $(0.09 \%)$. According to these results, it seems that none of the analyzed kinds of tea would be a good source of these elements. Oxalate results were assessed in view of recommendations of American 
Fig. 1 a Hierarchical dendrogram for the analyzed tea samples as objects in view of the kind of tea. b Hierarchical dendrogram for the analyzed elements in tea samples in view of the kind of tea

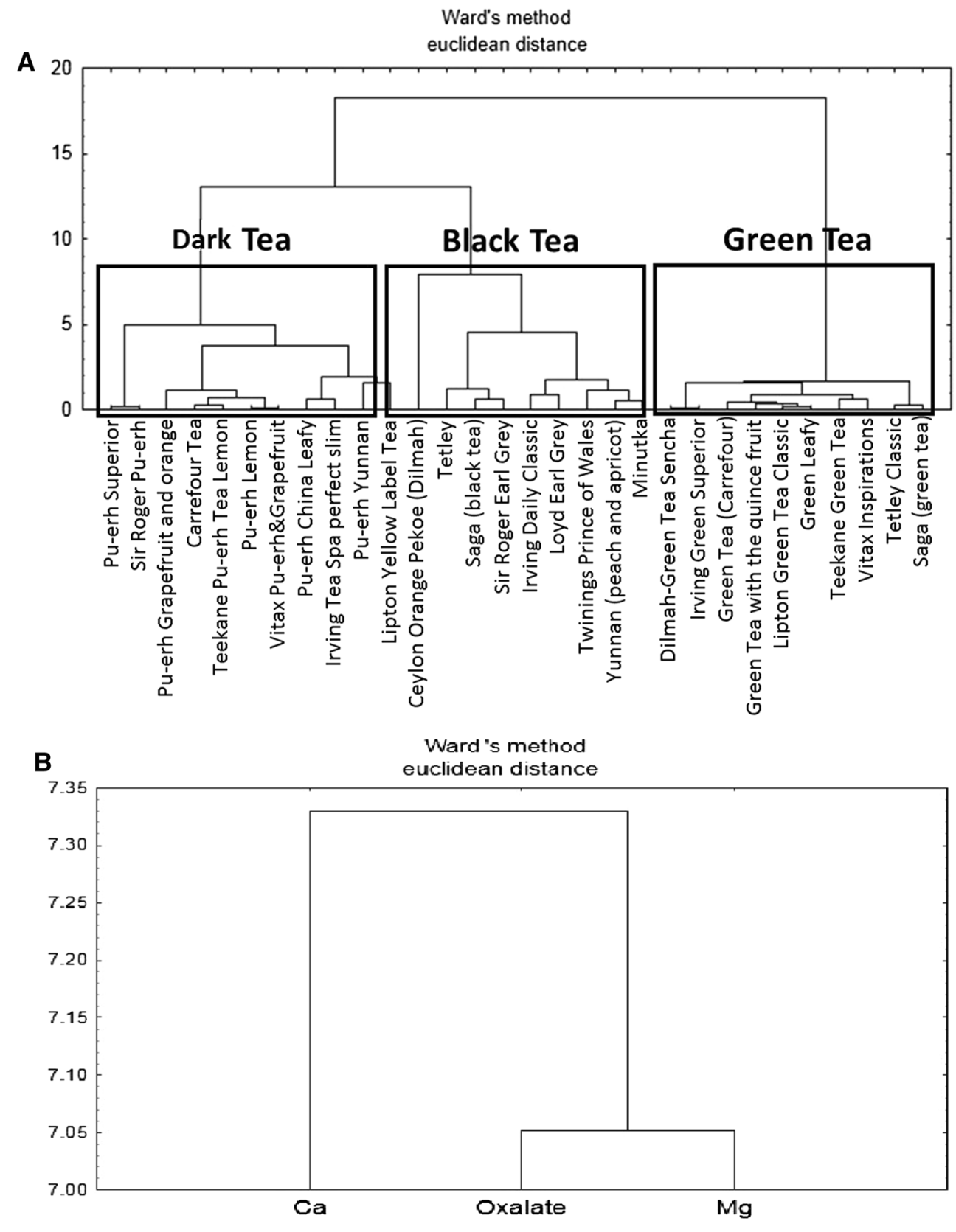

Dietetic Association. According to them, the levels of oxalate for people with increased risk of kidney stones should not exceed 40-50 mg per day [46]. As people in Poland drink 2-3 times tea per day [47] and average bioavailability of oxalate is $9 \%$ [7], so from three cups of green tea (240 mg/600 mL) there will be absorbed $22 \mathrm{mg}$ of oxalate. In case of black tea $(468 \mathrm{mg} / 600 \mathrm{~mL}), 42 \mathrm{mg}$ of oxalate will be absorbed. Drinking on average three cups of dark tea $(672 \mathrm{mg} / 600 \mathrm{~mL})$ might result in absorption of $60 \mathrm{mg}$ of oxalate. Therefore, it can be concluded that consumption of three cups of dark tea per day is more dangerous for people with risk of kidney stones than drinking the same amount of green tea. However, there are many anomalies in bioavailability and metabolism of oxalate in gastrointestinal tract, which could hinder the real estimate of oxalate absorption from tea [48].

\section{Discussion}

Bioavailability of studied components and health effects

Liebman and Costa [49] compared the effects of calcium carbonate and magnesium oxide on oxalate absorption. The results showed that $\mathrm{Ca}$ was more effective in oxalate absorption than $\mathrm{Mg}$ (62 and $44 \%$, respectively). About 
three-fourths of all kidney stones are composed primarily of calcium oxalate. However, $\mathrm{Mg}$ is a cation which can form more soluble complex with oxalate, than Ca complex, and would be also predicted as a protective agent against kidney stones. Therefore, it is important to keep the correct content ratio of $\mathrm{Mg}$ to $\mathrm{Ca}$. $\mathrm{Mg}$ has a higher affinity to oxalate, thus when $\mathrm{Mg}$ levels in diet are higher than $\mathrm{Ca}$ levels, it results in reduced ability of oxalate to crystallize in the stones [50]. As a consequence of reduced calcium oxalate level, formation of kidney stones in patients was not observed [51].

It was found that calcium salts contained in the urine do not crystallize due to the binding of about $80 \%$ of calcium ions with citrates, gluconates, urea and amino acids [51]. Dark tea, analyzed in this work, had higher levels of oxalate and macroelements and, thus, it represents higher risk for patients, who are exposed to the development of kidney stones. The content ratio of $\mathrm{Mg}$ to $\mathrm{Ca}$ in the analyzed teas (especially in dark teas) was too low to protect against formation of kidneys stones. Therefore, it seems reasonable to use the pharmaceuticals with magnesium in treatment of kidney stones [52]. Also dietary calcium restriction has been a mainstay of therapy for the prevention of recurrent kidney stones [51]. According to Noonan and Savage [53], sporadic consumption of high-oxalate foods does not lead to adverse health effects. Patients particularly affected are those whose diet is not enough varied, with a predominance of products rich in oxalate. The lowest content of oxalate in green tea suggests choosing this kind of tea by patients with developed kidney stones and in prevention of this disease. Furthermore, Jeong et al. [54] showed that green tea, despite the presence of free oxalate, also contains epigallocatechin gallate, which acts to hinder the formation of kidney stones.

\section{Conclusions}

The complex composition of tea contributes not only to positive but also adverse effects of its consumption on the human body. The analyzed kinds of tea characterized with different oxalate contents. The highest levels of oxalate were determined in the analyzed samples of dark and black tea. Black tea characterized with higher content of $\mathrm{Mg}$ and $\mathrm{Ca}$ than other teas. However, the content ratio of $\mathrm{Mg}$ to $\mathrm{Ca}$ in the analyzed teas was too low to protect against the formation of kidneys stones; thus, it seems reasonable to use magnesium pharmaceuticals in treatment of kidney stones. Based on the results, it was confirmed that people with hyperoxaluria or a tendency to form kidney stones should avoid dark and black tea. The lowest content of oxalate in green tea suggests choosing this kind of tea, but it is only one of the products consumed, so it is necessary to consciously control daily diet in view of oxalate content.

\section{Compliance with ethical standards}

Conflict of interest The authors declare that they have no conflicts of interest.

Ethical standards The manuscript does not contain clinical studies or patient data.

Open Access This article is distributed under the terms of the Creative Commons Attribution 4.0 International License (http://creativecommons.org/licenses/by/4.0/), which permits unrestricted use, distribution, and reproduction in any medium, provided you give appropriate credit to the original author(s) and the source, provide a link to the Creative Commons license, and indicate if changes were made.

\section{References}

1. Shen FM, Chen HW (2008) Element composition of tea leaves and tea infusions and its impact on health. Bul Environ Contam Toxicol 80:300-304

2. Chen L, Yu FL, Tong QQ (2000) Discussion on phylogenetic classification and evolution of sect. Thea. J Tea Sci 20:89-94

3. Wang HF, Provan GJ, Helliwell K (2000) Tea flavonoids: their functions, utilisation and analysis. Trends Food Sci Technol 11:152-160

4. Hilal Y, Engelhardt U (2007) Characterisation of white teacomparison to green and black tea. J Verbr Lebensm 2:414-421

5. Lv H-P, Zhang Y-J, Lin Z, Liang Y-R (2013) Processing and chemical constituents of Pu-erh tea: a review. Food Res Int 53:608-618

6. Trevisanato SI, Kim YI (2000) Tea and health. Nutr Rev 58:1-10

7. Liebman M, Murphy S (2007) Low oxalate bioavailability from black tea. Nutr Res 27:273-278

8. Kozukue E, Kozukue N, Kurosaki T (1983) Organic acid, sugar, and amino acid composition of bamboo shoots. J Food Sci 48:935-938

9. Wong MH, Hang ZQ, Wong JWC, Lan CY (1998) Trace metal contents $(\mathrm{Al}, \mathrm{Cu}$ and $\mathrm{Zn})$ of tea: tea and soil from two tea plantations, and tea products from different provinces of China. Environ Geochem Health 20:87-94

10. Han W, Zhao F, Shi Y, Ma L, Ruan J (2006) Scale and causes of lead contamination in Chinese tea. Environ Pollut 139:125-132

11. Tascloglu S, Kok E (1998) Temperature dependence of copper, iron, nickel and chromium transfers into various black and green tea infusions. J Sci Food Agric 76:200-208

12. Honow R, Reinhold Gu K-L, Hesse A, Siener R (2010) Oxalate content of green tea of different origin, quality, preparation and time of harvest. Urol Res 38:377-381

13. Morita A, Suzuki R, Yokota H (2004) Effect of ammonium application on the oxalate content of tea plants (Camellia sinensis L.). Soil Sci Plant Nutr 50:763-769

14. Jaworska G (2005) Nitrates, nitrites, and oxalates in products of spinach and New Zealand spinach. Food Chem 89:395-401

15. Kröppl M, Zeiner M, Juranovic CI, Stingeder G (2012) Differences in aluminium content of various tea powders (black, green, herbal, fruit) and tea infusions. Eur Chem Bull 1:382-384 
16. McKenzie JS, Jurado JM, Pablos F (2010) Characterisation of tea leaves according to their total mineral content by means of probabilistic neural networks. Food Chem 123:859-864

17. Ghosh Das S, Savage GP (2012) Total and soluble oxalate content of some Indian species. Plant Foods Hum Nutr 67:186-190

18. Liebman M, Al-Wahsh I (2011) Probiotics and other key determinants of dietary oxalate absorption. Adv Nutr 2:254-260

19. Szczeklik A, Gajewski P (2014) Interna Szczeklika. Medycyna Praktyczna, Kraków

20. Fanci AS, Braunwald E, Kasper DL, Hauser SL, Longo D, Larry-Jameson J (2008) Interna Harrisona. Czelej Sp. z o.o, Lublin

21. Curhan GC (2007) Epidemiology of stone disease. Urol Clin North Am 34:287-293

22. Grembecka M, Malinowska E, Szefer P (2007) Differentiation of market coffee and its infusions in view of their mineral composition. Sci Total Environ 383:59-69

23. Michalak-Majewska M (2010) Evaluation of oxalate content in popular infusions of teas and coffees. Bromat Chem Toksykol 1:74-279 (in Polish)

24. Sperkowska B, Bazylak G (2010) Evaluation of oxalate content in brews of black teas and coffees available in Poland. Nauka Przyroda Technol 4:1-13 (in Polish)

25. Rusinek E (2010) Evaluation of soluble oxalates content in infusions of different kinds of tea and coffee available on the Polish market. Roczniki PZH 63:25-30

26. Sperkowska B, Bazylak G (2010) Effect of extraction conditions on the soluble oxalate content in water infusions of green and herbal teas. Żywność Nauka Technol Jakość 4:107-121 (in Polish)

27. Charrier MJS, Savage GP, Vanhanen L (2002) Oxalate contents and calcium binding capacity of tea and herbal teas. Asia Pac J Clin Nutr 11:298-301

28. Fernández-Cáceres PL, Martín MJ, Pablos F, González AG (2001) Differentiation of tea (Camellia sinensis) varieties and their geographical origin according to their metal content. J Agric Food Chem 49:4775-4779

29. Marcos A, Fischer A, Rea G, Hill SJ (1998) Preliminary study using trace element concentrations and a chemometrics approach to determine geographical origin of tea. J Anal At Spectrom 13:521-525

30. Moreda-Piñeiro A, Fisher A, Hill SJ (2003) The classification of tea according to region of origin using pattern recognition techniques and trace metal data. J Food Compos Anal 16:195-211

31. Fung KF, Carr HP, Poon BHT, Wong MH (2009) A comparison of aluminum levels in tea products from Hong Kong markets and in varieties of tea plants from Hong Kong and India. Chemosphere 75:955-962

32. Fung KF, Zhang ZQ, Wong JWC, Wong MH (2003) Aluminium and fluoride concentrations of three tea varieties growing at Lantau Island, Hong Kong. Environ Geochem Health 25:219-232

33. Mehra A, Baker CL (2007) Leaching and bioavailability of aluminium, copper and manganese from tea (Camellia sinensis). Food Chem 100:1456-1463

34. Seenivasan S, Manikandan N, Muraleedharan NN, Selvasundaram R (2008) Heavy metal content of black teas from South India. Food Control 19:746-749

35. Szymczycha-Madeja A, Wełna M, Pohl P (2012) Elemental analysis of teas and their infusions by spectrometric methods. Trends Anal Chem 35:169-171
36. Qin F, Chen W (2007) Lead and copper levels in tea samples marketed in Beijing, China. Bull Environ Contam Toxicol 79:247-250

37. Malik J, Szakova J, Drabek O, Balik J, Kokoska L (2008) Determination of certain micro and macroelements in plant stimulants and their infusions. Food Chem 111:520-525

38. Matsuura H, Hokura A, Katsuki F, Itoh A, Haraguchi H (2001) Multielement determination and speciation of major-to-trace elements in black tea leaves by ICP-AES and ICP-MS with the aid of size exclusion chromatography. Anal Sci 17:391

39. Malinowska E, Gulewicz J, Kośmider M, Szefer P (2003) The content of chemical elements in the oolong teas and evaluation of minerals leaching into infusions. Bromat Chem Toksykol 36:395-399

40. Salahinejad M, Aflaki F (2010) Toxic and essential mineral elements content of black tea leaves and their tea infusions consumed in Iran. Biol Trace Elem Res 134:109-117

41. Ipeaiyeda AR, Dawodu M (2011) Leaching of manganese, iron, copper and zinc from tea (Camellia sinensis) in tea mugs. J Environ Agric Food Chem 10:2240

42. Dambiec M, Polechońska L, Klink A (2013) Levels of essentials and non-essential elements in black teas commercialized in Poland and their transfer to tea infusion. J Food Compos Anal 31:62-66

43. Gallaher RN, Gallaher K, Marshall AJ, Marshall AC (2006) Mineral analysis of ten types of commercially available tea. J Food Compos Anal 19:S53-S57

44. Szefer P (2007) Chemometric techniques in analytical evaluation of food quality. In: Szefer P, Nriagu JO (eds) Mineral components in foods. CRC Press, Boca Raton, pp 70-111

45. Jarosz M (2012) Human nutrition standards for the Polish population-amendment. IŻŻ, Warsaw (in Polish)

46. Marcason W (2006) Where can I find information on the oxalate content of foods? J Am Diet Assoc 106:627-628

47. Wojciechowska-Mazurek M, Starska K, Mania M, Rebeniak M, Karłowski K (2010) Elements harmful to health in tea-estimation of health hazard. Bromat Chem Toksykol 3:233-239 (in Polish)

48. Spadło A, Kowalewska-Pietrzak M, Młynarski W (2008) Use of probiotics in prevention and therapy of hyperoxaluria and calcium-oxalate stone disease. Przegl Pediatr 38:218-221 (in Polish)

49. Liebman M, Costa G (2000) Effects of calcium and magnesium on urinary oxalate excretion after oxalate loads. J Urol 163:1565-1569

50. Sułowicz W, Kucharska E, Kmiecik J, Ochmański W (1997) Etiology and pathogenesis of urolithiasis. Przegl Lek 54:173-179 (in Polish)

51. Szczurek E, Słodowska-Hajduk Z, Thor P (1999) The level of inhibitors of crystallization (magnesium) in urine urolithiasis patients. Urol Pol 52:4-7 (in Polish)

52. Jarzyło E (1996) Some problems of the recurrent urolithiasis. Urol Pol 49:200-209 (in Polish)

53. Noonan SC, Savage GP (2009) Oxalate content of foods and its effect on humans. Asia Pacific J Clin Nutr 8:64-74

54. Jeong BC, Kim BS, Kim JI, Kim HH (2006) Effects of green tea on urinary stone formation: an in vivo and in vitro. Study $\mathbf{J}$ Endourol 20:356-361 